\title{
The Expert Perception on Development and Usability of Teaching Aids 'Kit' Mini Model (Cage System) for Aquaculture Course
}

\author{
${ }^{1}$ Hafizi Harun, ${ }^{1}$ Zalina Ismail*, ${ }^{1}$ Asilah Abdul Mutalib, ${ }^{2 Z a h i d a h ~ A b ~ L a t i f, ~}{ }^{3}$ Shaibatul \\ 'Islamiah Che Man
}

Email : zalina.ismail@ftv.upsi.edu.my*

*: coresponding author

${ }^{1}$ Agricultural Science Department, Faculty of Technical and Vocational, Universiti Pendidikan Sultan Idris, 35900 Tanjong Malim, Perak, Malaysia

${ }^{2}$ Family and Consumer Science, Faculty of Technical and Vocational, Universiti Pendidikan Sultan Idris, 35900 Tanjong Malim, Perak, Malaysia

${ }^{3}$ Centre of Studies for Landscape Architecture, Faculty of Architecture, Planning and Surveying, Universiti Teknologi MARA, UiTM Puncak Alam, 42300 Puncak Alam, Selangor.

Article history

Received July 02, 2021

Revised Nov 26, 2021

Accepted Nov 30, 2021

Keywords

ADDIE model

Teaching 'Kits'

Mini-models

Cage system.
The increasing technology as changed the learning methods nowadays which clearly presents a new challenge to educators. Moreover, following the COVID-19 pandemic that hit the world at this time completely inhibits the teaching and learning process to be done entirely online. This clearly presents difficulties to teachers and students, as there are subjects that require practice to improve skills and better understanding. Among the limited access for teachers during the online learning and teaching process is that teachers can only explain and display pictures and show videos. At the same time, students need skills and understanding related to a subject studied. Also, students may not be able to accurately identify the types of systems found in the subjects studied. For example, for aquaculture subjects, the process of online teaching and learning can actually be done. However, this subject also requires practical and field work for students. In aquaculture subjects, in particular, teaching aids play an important role in understanding the cage farming system concept in the teaching process because there are various farming systems used in the aquaculture industry. The development of teaching aid is a crucial phase to make sure the teaching aids develop in accordance with the objectives and topics learning. Therefore, it is important to have an expert perception of the development and usability of the "Teaching Aids 'kit' mini model (Cage system). This study consisted of 9 experts as an evaluator consisting of experienced lecturers in the technical field of Faculty Technical. This study uses a quantitative assessment method (questionnaire). A set of questionnaires was distributed to the experts to obtain the required information and data. All data obtained were analyzed using computer software' Statistical Package For Social Science SPSS version 24 to obtain the frequency, percentage and mean through descriptive statistic. The study's findings show that the level of experts' perception of "Teaching Aids 'kit' mini model (Cage system) development and usability is necessary and positive. The study's conclusion illustrates the need for the development of a teaching aids' kit' mini model (cage system) for teachers to increase the level of 
understanding and skills of individual students in the teaching and learning process for aquaculture subjects.

This is an open access article under the $\mathrm{CC}-\mathrm{BY}-\mathrm{SA}$ license.

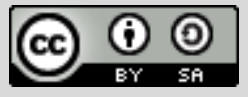

\section{Introduction}

With the use of technology that can provide a more interactive learning process to increase understanding and engage students, increasingly sophisticated technology has changed the method of learning. According to Ulrahman et al., (2017), one-way teaching and learning process from teachers alone still cannot guarantee an effective teaching and learning process without going through teaching aids. Also, the COVID-19 pandemic completely inhibits the teaching and learning process that was once possible in schools, has forced the teaching and learning process to be done entirely online.

Before the COVID-19 pandemic was detected, the teaching and learning process was conducted face to face where practical classes required students to experience the teaching and learning process directly and provide more understanding and improve individual skills. Due to the covid-19 pandemic situation that is plaguing the country at this point which has a lot of impact on the educational. This clearly presents difficulties to the ministry, which must change the methods and processes of 'face-to-face' teaching and learning in schools and institutions of higher learning to online teaching and learning processes.

Among the limited access for teachers during the online learning and teaching process is that teachers can only explain and display pictures and show videos. At the same time, students need skills and understanding related to a subject studied. Besides, this situation also clearly presents difficulties to teachers and students, as there are subjects that require practical lesson to improve skills and better understanding. For example, for aquaculture subjects, practical and fieldwork are requiring for students. Also, students may not be able to accurately identify the types of systems such as cage system found in the subjects studied.

Therefore, in aquaculture subjects, in particular, teaching aids play an important role in understanding the cage farming system concept in the teaching process because there are various farming systems used in the aquaculture industry.

Teaching aids are a medium explicity used in the teaching and learning process that is often used in schools and at the university level to encourage learning sessions to be easier (Othman Abdelaziz Ahmed, 2018). According to Othman Abdelaziz Ahmed (2018) stated that teaching aids are also able to play a role as 'Assistant' to teachers in the teaching and learning 
process such as explaining, creating, coordinating concepts accurately as well as more effective and clear interpretation and understanding.

Therefore, in this study, it is important to have an expert perception to answer the following questions: (1) What are expert perceptions of the elements for the development of teaching aids' kit' mini model (cage system)? (2) What are expert perceptions of the development (design and layout) of teaching aids' kit' mini model (cage system)? (3) What are expert perceptions of the usability of teaching aids' kit' mini model (cage system)?

\section{Theoretical Framework (ADDIE Model)}

The ADDIE model is a model used in the study of the development of a product to solve problems encountered (Stapa \& Mohammad, 2019). The ADDIE model is divided into five phases and steps that include analysis, design, development, implementation and evaluation (Figure 1). This ADDIE model is also one of the models used in the field of design to produce an effective design.

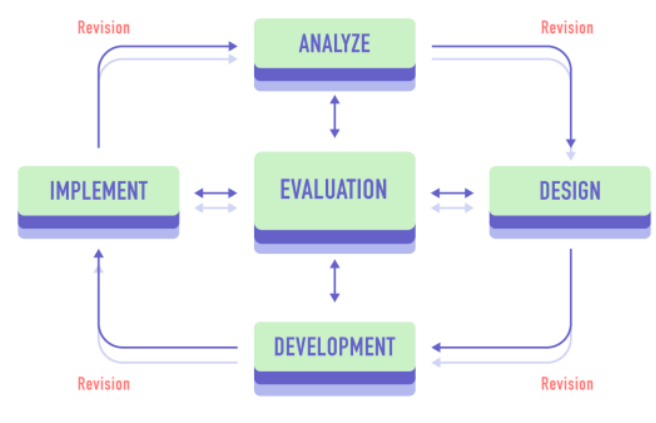

Figure 1: ADDIE Framework (Aldoobie, 2015)

Analysis phase to develop a teaching aids' kit' mini model (cage system), the researcher conducted a survey questionnaire given to semester four students (AT09). The questionnaire is a needs analysis study used to obtain information and data related to students. Also, the information is necessary for the development of teaching aids. Needs analysis data collection using questionnaire instruments is recommended (Sönmez, 2019 and Ali et al., 2013).

Design process is important before instructional product development. According to McKenney \& Reeves (2012); Bacotang et al., (2016), this stage is essential to build the 'kit' development objectives and determine the general goal of the mini model 'kit' developed. In addition, the form selection process plays an important role for the desired purpose to be carried out through a process that is understood of the instructional product used.

Development phase will be much easier if the phase appropriately planned. This development phase carried out to see the usability of the planned instructional product. Also, this development phase is to carry out improvements, if possible, errors, select support media, develop 
guidelines and instructions as guidance methods, perform format revisions and conduct pilot studies before the instructional product is implemented/developed (Kurt Serhat, 2017).

Implementation phase is the actual delivery phase of the model teaching aids for use in the teaching and learning process tested on experts and refers to the implementation steps. To facilitate installation and use of this 'cage system' mini model teaching and learning aid kit, manual (instruction) and video installation and use included. Every part of the material and manual for installation supplied to the expert. In addition, to make it easier for students to access the manual (instruction) and video, a QR code has been provided where experts only need to scan to see the content related to the installation and use process.

Evaluation is the process of collecting information and data related to the research conducted. In this stage, the researcher conducted a study that is the initial implementation of the need to develop a teaching aids' kit' mini model (cage system) for students of aquaculture subjects at the Sultan Idris Education University, Tanjong Malim, Perak.

\section{Method}

\section{Analysis Phase}

The analysis phase is considered the 'Goal Setting Phase' which focuses on planning targeted to the audience. According to Aldoobie (2015), in the process of conducting the analysis phase, the important thing to do is to analyze four things; (1) such as analyzing students (students 'presence, skills and needs), (2) developing instructional analysis (to provide necessary steps and present opportunities to learn and use new information), (3) create instructional objectives (determine desired end outcomes), and (4) analysis of learning objectives (measure achievement goals). In this phase, needs analysis was conducted to gain information from a student to determine if the teaching aid is necessary or not to be built in this phase. Set of questionnaires was distributed to the student using a google form. The questionnaire contains sections $\mathrm{A}$ (Demographics) and section B (Needs Analysis Study - 12 items). This study used a 5-point Likert scale ranging from 1 (strongly disagree) to 5 (strongly agree).

\section{Design Phase}

This study uses the approach of a teaching aids' kit' mini model (cage system). Therefore, the determination of the size and shape of the model should be set to facilitate instructional product development. In addition, the use of readily available and inexpensive materials is a priority in the planning and design of this instructional product. After that, the designed instructional product needs to expressed in the form of drawings by labelling each component used. This process is important because the drawing will be a reference source for the future instructional product development phase (Figure 2). 


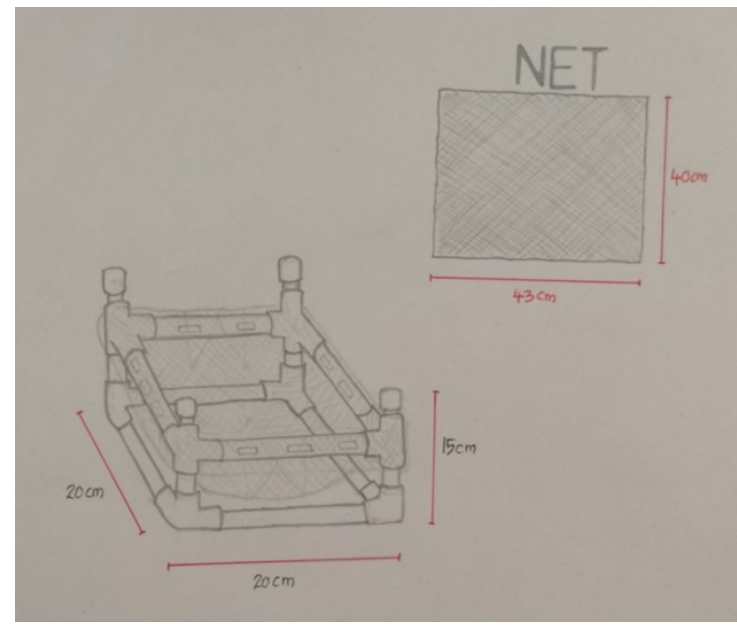

Figure 2: Illustration of Teaching Aids 'kit' mini model (Cage system)

\section{Development Phase}

Referring to applications in aquaculture subjects, a teaching aids 'kit' mini model (cage system) is the idea of forming teaching aids consisting of materials that have buoyancy characteristics, such as the use of pipes and nets to carry out the process of fish farming. The materials and components (Figure 3) used for the formation of this mini model are PVC pipes, PVC connectors and mosquito nets that are cheap and readily available in the market. The idea sparked when the world hit by the COVID-19 pandemic impacted the teaching and learning process that has been converted to online learning.

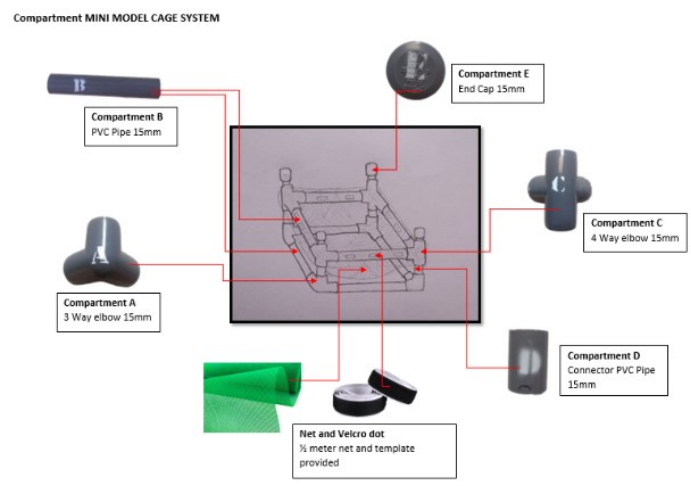

Figure 3: Compartment Teaching Aids 'kit' mini model (Cage system)

\section{Implementation Stages}

The implementation phase is the actual delivery phase of the model teaching aids for use in the teaching and learning process tested on experts. To facilitate installation and use of this a teaching aids 'kit' mini model (cage system), manual (instruction) and video installation and use included. Every part of the material and manual for installation supplied to the expert. In addition, to make it easier for students to access the manual (instruction) and video, a QR code has been provided where experts only need to scan to see the content related to the installation and use process (Figure 4 and 5). 


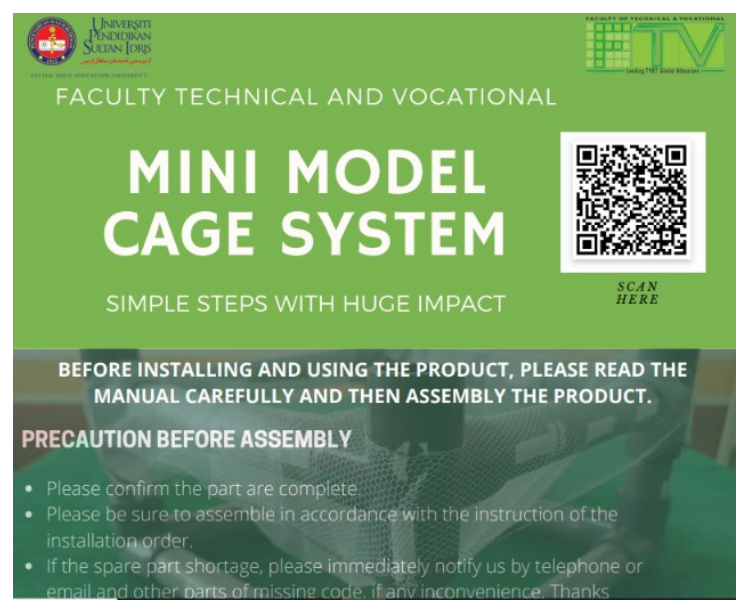

Figure 4: Manual (Instruction) for assembly Teaching Aids 'kit' mini model (Cage system)

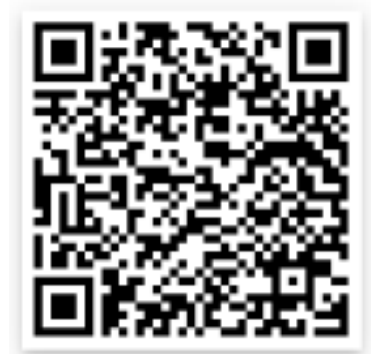

Figure 5: QR Code for access installation and use manual and video

\section{Evaluation Stages}

Evaluation is the process of collecting information and data related to the research conducted. In this stage, the researcher conducted a study that is the initial implementation of the need to develop a teaching aids' kit' mini model (cage system) for students of aquaculture subjects at the Sultan Idris Education University, Tanjong Malim, Perak. The study involved nine expert evaluators in evaluating the teaching aids' kit' mini model (cage system). Each respondent's feedback was determining the level of need for teaching aids that can influence students' understanding and skills.

\section{Instrument Development (Questionnaire)}

The method use for the quantitative approach is via survey questionnaires. This study used the 2-point Likert scale ranging from 1 (No) to 2 (Yes) to acquire the perception of the respondents. The questionnaire consisted of four sections. The first section included a total of 5 items of demographic information of respondents. The second section part consisted of 19 items to evaluate expert perception of essential elements of teaching aid and necessary features for teaching aid. The third section consisted of 14 items to evaluate expert perception of development of teaching aids 'kit' mini model (cage system) (Design and Layout). The last section included 14 items to evaluate expert perception of usability of teaching aids 'kit' mini model (cage system). 


\section{Sampling and Data collection}

The target expert was lecturers who worked at Faculty of Technical and Vocational, Sultan Idris Education University. A self-administered questionnaire and Aquaponic Mini Model Learning Aid Kit was distributed to the expert in three department Faculty of Technical and Vocational. The experts were chosen based on their experience in developing learning aid kits, teaching pedagogy, and knowledge of agriculture in practice. A total of 10 questionnaires were distributed and 9 responses were returned, corresponding to a response rate of $90 \%$. The survey was open for a week between June $2^{\text {nd }}$ and April 9th 2021.

\section{Data analyses}

The IBM SPSS Statistics 24 was utilized by conducting descriptive analysis to obtain statistics including mean, standard deviation, frequency, and percentage to summarize the data. Internal consistency of each identified construct was calculated to evaluate instrument reliability through Cronbach's alpha values.

\section{Result and Discussion}

\section{Demographic Profiles Respondents}

Table 1 shows frequencies and percentages for demographic variables. The majority of experts were female (77.8\%, female; $22.2 \%$, male). Most experts were 35 to 39 years $(55.6 \%)$ old in comparison to 30 to $34(22.2 \%), 25$ to $30(11.1 \%) 40$ to $44(11.1 \%)$ age groups. The majority of The majority of experts held a certificate of $\mathrm{PhD}(77.8 \%)$ and 22.2\% held a Master degree. Data showed that $100 \%$ of the experts work as a lecturer.

Table 1: Demographic profile respondents

\begin{tabular}{llcc}
\hline \multicolumn{1}{c}{ Variable } & \multicolumn{1}{c}{ Category } & Frequency & $\%$ \\
\hline Gender & Male & & \\
& Female & 2 & 22.2 \\
Age (Years) & $25-30$ & 7 & 77.8 \\
& $30-32$ & 1 & 11.1 \\
& $35-39$ & 2 & 22.2 \\
Level Education & $40-44$ & 5 & 55.6 \\
& Master & 1 & 11.1 \\
Profession & PhD & 2 & 22.2 \\
& University lecturer & 7 & 77.8 \\
& & 9 & 100 \\
\hline
\end{tabular}




\section{Expert perception on essential element of teaching aid}

Table 2 presents means and standard deviations of expert perception on essential elements of teaching aid. Data interpretation is made based on the mean value obtained, whether weak (0.0-0.1.86), moderate (1.87-1.93) and good (1.94-2.00). The overall mean perception rating was 2.00, implying perceptions were good. The highest mean for essential element of teaching aid was teaching that related to the topic of learning, teaching aid makes teaching more engaging and offer real experience and increase student understanding of the lesson content.

Table 2: Means and Standard Deviations of Expert Perception on Essential Elements of Teaching Aid

\begin{tabular}{lcc}
\hline \multicolumn{1}{c}{ Item } & Mean & SD \\
\hline $\begin{array}{l}\text { Teaching aid related to the topic of learning } \\
\text { The content of the teaching aid is accurate and closely related to the }\end{array}$ & 2.00 & .000 \\
$\begin{array}{l}\text { topic to be taught } \\
\begin{array}{l}\text { Teaching aid help make students learn more about the understanding } \\
\text { of the content of the lesson }\end{array}\end{array}$ & 2.00 & .000 \\
$\begin{array}{l}\text { Teaching aid offers an real experience and makes teaching more } \\
\text { interesting }\end{array}$ & 2.00 & .000 \\
$\begin{array}{l}\text { Teaching aid can encourage creativity, both to teachers and students } \\
\text { Teaching aid kits contain original and distinctive ideas and designs }\end{array}$ & 2.00 & .000 \\
$\begin{array}{l}\text { Teaching aid contain high pure values (not using materials such as } \\
\text { polite pictures or using materials that contain negative elements such }\end{array}$ & 1.89 & .441 \\
as gambling and smoking). & & \\
\hline
\end{tabular}

\section{Expert perception on necessary features for teaching aid}

Table 3 presents means and standard deviations of expert perception on necessary features for teaching aid. Data interpretation is made based on the mean value obtained, whether weak (0.0-0.1.86), moderate (1.87-1.93) and good (1.94-2.00). The overall mean perception rating was 2.00, implying perceptions were good. The highest mean for necessary features of teaching aid was teaching aids that facilitate students and teaching aids that use low cost in development and the design of the teaching aid mini model 'cage system' developed easy for students to use. 
Table 3: Means and standard deviations of expert perception on necessary features for teaching aid. (TA: Teaching aid)

\begin{tabular}{lcc}
\hline \multicolumn{1}{c}{ Item } & Mean & SD \\
\hline TA is simple and achieve learning objectives & 2.00 & .000 \\
TA is medium-sized and easy to carry & 2.00 & .000 \\
TA included with the user or installation manual & 2.00 & .000 \\
TA can facilitate students & 2.00 & .000 \\
Innovative teaching aid kit (QR code scan and video on how to use or & 1.89 & .333 \\
install) & & \\
TA that uses actual materials & 1.89 & .333 \\
TA using low-cost materials & 2.00 & .000 \\
TA which is neat and clean & 1.89 & .333 \\
TA have appropriate graphics and writing (user manual) & 1.89 & .333 \\
TA can be used many times and is durable & 1.89 & .333 \\
TA kit is realistic and easy to understand & 1.78 & .441 \\
TA has physical features - safe, easy to use and store & 2.00 & .000 \\
\hline
\end{tabular}

Expert perception on development of Aquaponic Mini Model Learning Aid Kit (design and layout)

Table 4 presents means and standard deviations of expert perception on development of teaching aids' kit' mini model (cage system) (design and layout). Data interpretation is made based on the mean value obtained, whether weak (0.0-0.1.86), moderate (1.87-1.93) and good (1.942.00). The overall mean perception rating was 2.00 , implying perceptions were good. The highest mean for development of teaching aids' kit' mini model (cage system) (design and layout) was the teaching aids mini model 'cage system' developed is easy to understand by students and the design of teaching aids 'cage system' mini model teaching and learning aid kit in accordance with the learning objectives.

Table 4: Means and standard deviations of expert perception on development of teaching aids 'kit' mini model (cage system) (design and layout)

\begin{tabular}{lcc}
\hline \multicolumn{1}{c}{ Item } & Mean & SD \\
\hline $\begin{array}{l}\text { The design of the teaching aid mini model 'cage system' developed in } \\
\text { accordance with the learning objectives }\end{array}$ & & .000 \\
$\begin{array}{l}\text { The design and layout of the teaching aid mini model 'cage system' } \\
\text { developed attractive and convenient }\end{array}$ & 1.89 & .333 \\
\end{tabular}


The design of the teaching aid mini model 'cage system' developed

neatly and firmly

The size of the teaching aid mini model 'cage system' developed 2.00

suitable (medium size and easy to carry)

The design of the teaching aid mini model 'cage system' developed easy

for students to use

The design of teaching aid mini model 'cage system' developed to suit

The information on the teaching aid mini model 'cage system'

The components of the teaching aid mini model 'cage system'

developed easy to disassemble if misused or installed

The components of the teaching aid mini model 'cage system'

developed using materials that are easily available and cheap

The user manual included with the model teaching aid mini model

'cage system' developed have innovative value (QR code scan and video)

The user manual included with the teaching aid mini model 'cage

system' developed interesting and clear

The instructions in the user manual or installation of the teaching aid

mini model 'cage system' developed clear

The writing on the user manual or installation of the teaching aid mini

model 'cage system' developed clear and easy to read

The visuals and audio used in the video on how to use or install the

teaching aid mini model 'cage system' developed interesting and appropriate

\section{Expert perception on usability of teaching aids 'kit' mini model (cage system)}

Table 5 presents means and standard deviations of expert perception on usability of teaching aids' kit' mini model (cage system). Data interpretation is made based on the mean value obtained, whether weak (0.0-0.1.86), moderate (1.87-1.93) and good (1.94-2.00). The overall mean perception rating was 2.00 , implying perceptions were good. The highest mean for Usability of teaching aids' kit' mini model (cage system) was the of teaching aids developed to facilitate the teaching and learning process, teaching aids can stimulate students' thinking to a more critical and 
use of the teaching aids 'kit' mini model (cage system) can increase students' practical skills during online learning.

Table 5: Means and standard deviations of expert perception on usability of teaching aids 'kit' mini model (cage system)

\begin{tabular}{|c|c|c|}
\hline Item & Mean & SD \\
\hline $\begin{array}{l}\text { Teaching aids 'kit' mini model (cage system) developed achieved } \\
\text { learning objectives }\end{array}$ & 2.00 & .000 \\
\hline $\begin{array}{l}\text { Teaching aids 'kit' mini model (cage system) developed facilitates } \\
\text { teaching and learning }\end{array}$ & 2.00 & .000 \\
\hline Teaching aids 'kit' mini model (cage system) developed works well & 2.00 & .000 \\
\hline $\begin{array}{l}\text { Teaching aids 'kit' mini model (cage system) developed can elicit } \\
\text { students' creative and critical thinking }\end{array}$ & 1.89 & .333 \\
\hline $\begin{array}{l}\text { Teaching aids 'kit' mini model (cage system) developed can replace } \\
\text { hands-on activities during online learning }\end{array}$ & 1.89 & .333 \\
\hline $\begin{array}{l}\text { Teaching aids 'kit' mini model (cage system) developed can hone } \\
\text { students' practical skills during online learning }\end{array}$ & 2.00 & .000 \\
\hline $\begin{array}{l}\text { The level of usability of the teaching aids 'kit' mini model (cage system) } \\
\text { mini model teaching aid kit developed is at a high level }\end{array}$ & 1.78 & .441 \\
\hline \multicolumn{3}{|l|}{$\begin{array}{l}\text { The use of teaching aids 'kit' mini model (cage system) developed does } \\
\text { not require lecturers or teachers to work overtime to build teaching aid }\end{array}$} \\
\hline & 1.78 & .441 \\
\hline $\begin{array}{l}\text { The use of teaching aids 'kit' mini model (cage system) developed in } \\
\text { teaching and learning is more time saving }\end{array}$ & 2.00 & .000 \\
\hline $\begin{array}{l}\text { The use of teaching aids 'kit' mini model (cage system) developed in } \\
\text { aquaculture teaching will help students learn to relate real equipment } \\
\text { with cage system }\end{array}$ & 2.00 & .000 \\
\hline $\begin{array}{l}\text { The use of the teaching aids 'kit' mini model (cage system) developed } \\
\text { is a fun and easy way to introduce and illustrate the concept of cage } \\
\text { system }\end{array}$ & 2.00 & .000 \\
\hline $\begin{array}{l}\text { The use of teaching aids 'kit' mini model (cage system) developed is } \\
\text { very important to cultivate students' curiosity }\end{array}$ & 2.00 & .000 \\
\hline $\begin{array}{l}\text { The use of teaching aids 'kit' mini model (cage system) developed is } \\
\text { very important to increase student involvement in teaching and } \\
\text { learning activities in the classroom online }\end{array}$ & 2.00 & .000 \\
\hline
\end{tabular}


The use of teaching aids 'kit' mini model (cage system) developed is

very important to increase students' understanding of the concept of cage system

\section{Discussion}

The study's findings have proven expert perception on essential elements of teaching aid is at a good level. The teaching aids used should be appropriate for the teaching and learning activities. According to Khairulameera (2011) the use of teaching aids is an approach to stimulate students' interest and focus on teaching and subsequently improve understanding and acquisition of knowledge and skills. Teaching aids are existing materials or anything that students can feel and experience (Omar et al., 2017). In addition, according to Ilias et al. (2013), poor creativity will be considered a barrier to using teaching aids. If teachers and lecturers use the same teaching aids for each teaching class, it will cause students to become bored quickly. Therefore, teaching aids used for teaching and learning must have a high intrinsic value (Khairulameera, 2011).

Expert perception on necessary features for teaching aid is at a good level. According to Noor Azlan and Nurdalina (2010), teaching aids can play an important role in understanding the concepts in the teaching process and can even attract students' interest in the subjects studied. Teaching aids can also be an important element in solving various teaching methods constantly changing teachers over time (Noor Azlan, Nurdalina, 2010). In addition, teaching aids that are appropriate to the topic of learning in a subject can help teachers deliver lessons more effectively. The use of teaching aids must be appropriately managed and efficiently so that students can understand and retain concepts or facts in their memory.

The study's findings have proven expert perception on development of the teaching aids' kit' mini model (cage system) is at a good level. The use of teaching aids should be adequately planned and efficiently so that students can understand and retain mathematical concepts or facts in their memory. Hamdan and Surizan (2010), stated that teaching aids developed will increase understanding and mastery of the subject. Teaching aids used should be appropriate for teaching and learning activities to achieve the targeted objectives (Khairulameera, 2011). A teacher should also be skilled in identifying, deciding to select the most effective teaching aids and optimizing resources to achieve the planned teaching objectives throughout the teaching process (Najamuddin, 2017).

According to Azman et al. (2014), conventional learning processes such as 'chalk and talk' and textbooks no longer guarantee effectiveness in teaching and learning because of the lack of ability to test and challenge students' level of thinking ability and imagination. Noor Azlan \& Nurdalina (2010), stated that good teaching aids can stimulate students' thinking to a more critical 
and high level. In addition, the quality of teaching with the use of teaching aids can also be improved and can solve the learning problems of teachers and lecturers that are constantly changing over time. According to Omar et al. (2017), the use of teaching aids that coincide with the subject taught could positively impact on the teaching and learning process. According to Azman et al. (2014), teaching aids will help teachers in terms of time management. It is emphasized that every teacher or lecturer should be sensitive to the development and changes of technology and the teaching process according to the passage of time-related to education.

\section{Conclusion}

Based on this study, the level of expert perception on the development and usability of Teaching Aids 'Kit' Mini Model (Cage System) for aquaculture course is high and on an agreed scale. According to the results, improvements must be made in the manuals and instructions for the teaching aid "kit" mini model (Cage System). The results of the analysis also showed positive feedback among experts. Therefore, developing a teaching aid "kit" mini model (Cage System) is necessary.

\section{References}

Aldoobie, N. (2015). ADDIE Model. American International Journal of Contemporary Research, $5(6), 68-72$.

Ali, H. I. H. \& Abdalla Salih, A. R. (2013). Perceived views of language teachers on the use of needs analysis in ESP materials writing. English Language Teaching, 6(3), 11-19.

Azman, M. N. A., Azli, N. A., Mustapha, R., Balakrishnan, B. \& Isa, N. K. M. (2014). Penggunaan alat bantu mengajar ke atas guru pelatih bagi topik kerja kayu, paip dan logam. Sains Humanika, 3(1).

Bacotang, J., Mohamed Isa, Z., Che Mustafa, M., Arshad, M. \& Omar, A. (2016). Aplikasi Model Addie Dalam Pembangunan Modul Literasi Awal (Modul Lit-a) Untuk Awal Kanak-Kanak. Jurnal Pendidikan Bitara UPSI Edisi Khas, 9, 1-10.

Hamdan and Mohamad A'zmi, Surizan (2010) Penilaian Kesesuaian Bahan Bantu Mengajar Jangka Sudut Khas Bagi Mata Pelajaran Matematik. Penilaian Kesesuaian Bahan Bantu Mengajar Jangka Sudut Khas Bagi Mata Pelajaran Matematik . pp. 1-6.

Khairulameera. (2011). Kemahiran Pemilihan Dan Aplikasi Alat Bantu (ABM). https://khairulameera.wordpress.com/2011/10/20/ Kemahiran-pemilihan-dan-aplikasialat-bantu-mengajar-abm/[2 Jun 2021].

Kurt, S. (2019). ADDIE Model: Instructional Design. Educational Technology, 29.

Ilias, M. F., Ismail, M. F. \& Jasmi, K. A. (2013). Faktor Dorongan dan Halangan Penggunaan Bahan Bantu Mengajar oleh Guru Pendidikan Islam di Sekolah Bestari. 3rd International Conference on Islamic Education 2013 [ICIED2013]. 
McKenney, S. \& Reeves, T.C. (2013). Educational Design Research. In Handbook of research on educational communications and technology, 131-140. New York: Springer.

Najamuddin. (2017). Bahan bantu mengajar tingkat kemahiran dan kefahaman pelajar. Utusan Borneo Online. Tawau, Sabah, Malaysia. Retrieved from https://www.utusanborneo.com.my/2017/04/15/bahan-bantu-mengajar-tingkatkemahiran-dan-kefahaman-pelajar.

Noor Azlan, A. Z. \& Nurdalina. (2001). Penggunaan Bahan Bantu Mengajar Di Kalangan Guru Pelatih Utm. Jurnal Universiti Teknologi Malaysia, Fakulti Pendidikan, 1(1).

Othman Abdelaziz Ahmed, A. (2018). EFL Teachers' and Students' Approaches in Using Teaching Aids: A case Study. Arab World English Journal, 4(4), 109-124.

Omar, M. S., Saad, N. S. \& Dollah, M. U. (2017). Penggunaan bahan bantu mengajar guru matematik sekolah rendah. Jurnal Pendidikan Sains Dan Matematik Malaysia, 7(1), 32-46.

Sönmez, H. (2019). An Examination of Needs Analysis Research in the Language Education Process. International Journal of Education and Literacy Studies, 7(1), 8.

Stapa, M. A. \& Mohammad, N. (2019). The Use of Addie Model for Designing Blended Learning Application at Vocational Colleges in Malaysia. Asia-Pacific Journal of Information Technology \& Multimedia, 08(01), 49-62.

Ulrahman, D., Saad, M., Husaini, M. H., Izzuddin, M., Pisol, M., Shafiq, A., Razali, M. \& Mohd, S. (2017). Kekerapan Penggunaan Bahan Bantu Mengajar.1 ${ }^{\text {st }}$ International Conference on Research, Language, and Education (ICoRaLE2017). 